\title{
FILM WORKSHOPS AS POLYVOCAL PUBLIC SPHERES: MINOR CINEMAS IN SWEDEN
}

Résumé: La culture de l'atelier de cinéma est un phénomène négligé dans l'histoire et la recherche en cinéma. Cet article propose l'idée que les ateliers qui ont proliféré dans les années 1960, 1970 et 1980 ont souvent constitué des espaces publics au sens qu'Habermas, Negt ou Kluge donnent au terme. Portant attention à l'atelier de cinéma suédois Filmverkstan (1973-2001), cet article démontre que les films issus d'ateliers étaient en résonance avec les " modes de vie concrets " d'un public (Lebenszusammenhang) plutôt d'être des produits visant pour un marché spécifique. De plus, les ateliers offraient un accès à la réalisation à diverses personnes. Cette recherche sur les ateliers de cinéma en tant qu'espace public, comme culture de polyvocalité et comme pratique mineure du cinéma réagit de façon productive aux approches téléologiques et textuelles qui ont prévalu en études cinématographiques.

Eilm workshop culture, which was at its height in the 1970s, is a neglected phenomenon in film history and research. This neglect is mostly attributable to the dominance of textual interpretation among film scholars. Although there is a counter tradition in reception studies, a dichotomy has been fostered, formulating producer versus receiver, object versus public. This split was to be addressed by the various theories of the public sphere. The aim of this essay is to argue that the film workshops that flourished some decades ago often constituted true public spheres in Oskar Negt's and Alexander Kluge's sense. ${ }^{1}$ Accordingly, the rise of the Internet, with its immense audiovisual archives and platforms such as YouTube, has a prehistory in workshop culture in terms of openness and availability. Of course, contemporary moving image technology and the Internet have, due to economic affordability, user-friendly equipment, and unlimited distribution, actualized a public sphere of a different magnitude as, for example, Bjørn Sørenssen has recently shown. ${ }^{2}$ However, films at the workshops were not made in order to create vast publics. Rather they were produced to resonate with a public's "concrete way of life" (Lebenszusammenhang). All kinds of films were made by all kinds of people, as a sort of pre-digital YouTube. In order to encourage research into these former workshops, which we consider to be important for approaching and studying the heterogeneous audiovisual culture of today, we argue for the usefulness of three specific concepts: 
"minor cinema," "polyvocalities" and-according to our main claim-"public sphere." As our object of study we have chosen the Swedish co-operative FilmCentrum (Film Centre) and in particular the workshop Filmverkstan (The Film Workshop).

The co-ops in the U.S., most significantly San Francisco Canyon Cinema and the Filmmakers Co-op in New York, inspired several instances throughout Europe. Some of the European equivalents were working as co-ops according to the North-American model in which the filmmakers both owned and ran the organization; others were community- or state-based workshops that encouraged a broad range of different filmmaking in which the workshop was the co-owner of the rights to the films being produced. However, as a film practice, when it came to what kind of films that were made and what kind of film culture they promoted, the values and ways of working were usually quite similar. Due to lack of thorough comparative research about film co-ops and workshops in different countries we will use the notion of "workshop" in general, signifying both film co-ops and film workshops in Europe. For example, the two major Swedish film workshops, Film Centre and the Stockholm based Film Workshop differed partly when it came to organization, funding and output, but they also overlapped. Film Centre started off as a co-op and became very soon an organization for mostly professional filmmakers, but also founded regional film workshops throughout Sweden. These workshops provided local filmmakers-both amateurs and professionals-with facilities and equipment, and the funding was mostly public. The Stockholm Film Workshop, on the other hand, was exclusively state-funded in the beginning, but functioned in its daily practice in many ways similarly to a co-op. The Workshop was run by independent filmmakers; a distribution catalogue was produced and the income from film rentals was shared between the Workshop and the filmmakers. If one wanted to secure the distribution rights for a film that had been produced at the workshop, one only had to pay for the final print. Thus, the Film Workshop enabled work, but did not imply that the filmmaker lost his or her right to the work. It was fairly easy to get permission to use the facilities and many productions that started at the Workshop were completed elsewhere.

The Swedish workshops were, like their counterparts in Denmark and Germany, children of the efforts in the 1970s to democratize cultural policy by expanding the pool of participation in cultural production. Film, in particular, had been a very exclusive medium; with these new policies, and increasingly affordable film technology, it was more available to a range of producers. Substandard gauge film projectors had become quite ordinary public equipment, breaking the hegemony of the cinema theatres. When the Film Centre applied for money from the department of cultural affairs in 1968 in order to found a large co-op, they estimated that there were more than 25,000 film projectors for $16 \mathrm{~mm}$ in schools and other public organizations. This implied, according to the Centre, 
that film had now the opportunity to reach and create other publics than those produced by mainstream cinema.

In film studies, the most thorough and influential elaboration of the theories of the public sphere have been by Miriam Hansen, especially in her book Babel and Babylon. Hansen presents thorough and sophisticated readings in her seminal work in order to show how early cinema constituted an alternative public sphere "as a medium that allows people to organize their experience on the basis of their own context of living, its specific needs, conflicts, and anxieties." ${ }^{3}$ The weakness in Hansen's argument is that it reproduces a split between producer and receiver or object (film) and subject (experience). This is, in fact, quite paradoxical because Hansen draws on Negt's and Kluge's theory of the public sphere that is a theory of organizing a public and creating cultures of participation, interaction and self-presentation. However, since Hansen chooses as her object of study D. W. Griffith's monumental Intolerance and analyzes the public reception of the film on the basis of newspaper clippings she remains caught in the paradigm of textual analysis. Thus, the relations between producer, object (the film) and receiver (subject) and public remain theoretical, a way of "tracing possible relations" and a "possible horizon of expectation" as Hansen puts it, instead of producing an analysis of actual film cultural practices in which object and subject are inherently connected. ${ }^{4}$ Hansen's approach is hardly surprising as such; humanities and the arts have conventionally been practices for the interpretation of specific objects and artefacts.

Accordingly, even research that uses the public sphere concept as a starting point tends to rely upon textual analysis as a primary method. Textual analysis has always been a stable currency in the field. But it is surprising that counter public spheres such as cine-clubs, amateur organizations or film workshops that allowed people to organize their experience and to overcome the split between audience and artefact, have been ignored by so many film scholars. Those cultures and contexts call for theories of the public sphere. The reason for the ignorance is, of course, not only due to the dominance of textual analysis; cultural phenomena like film workshops are difficult to research as most material is not archived and a majority of the work never reached the public through traditional distribution and exhibition channels. But this departure from the norm is, on the other hand, a trajectory that leads directly to one of Negt's and Kluge's points: the real public spheres were the counter ones, those in the margins of dominant practices. This has been developed in some historical studies, overcoming the textual hegemony in the research of avant-garde film cultures, and notably by David E. James in a study of “The Miners' Campaign Tape Project” during the 1980s British miners' strike. ${ }^{5}$ Even if most of the research in question does not explicitly refer to Negt and Kluge, it deals with film culture as a counter public sphere.

Oskar Negt's and Alexander Kluge's major work, Öffentlichkeit und 
Erfahrung (Public Sphere and Experience), appeared in 1972 and was written in the spirit of the New Left. ${ }^{6}$ The book was essentially a critical assessment of Jürgen Habermas's work, Structural Transformation of the Public Sphere. The critique performed by Negt and Kluge in the early 1970s differs in one important sense from the interventions in the 1980s and 1990s that were largely discussed in North America and Great Britain and which were highly critical of Habermas's initial theory. Whereas feminists like Nancy Fraser or cultural studies scholars like Johan Fornäs pointed out that Habermas's public sphere presupposed an homogeneous bourgeois public, a historical subject that is identical with the middle-class male, Negt and Kluge's contribution underlined the importance of experience, or Erfahrung. ${ }^{7}$ The critique made in the spirit of postmodernism stressed how Habermas's vision of ideal reason was both naïve and based on the act of excluding a broad range of sub-groups. Negt and Kluge, on the other hand, emphasized that the formation of a public had to have a resonance in actual concrete life, or Lebenszusammenhang. Thus, whereas the postmodernists questioned the notion of rationality and unbiased communication, Negt and Kluge criticized the abstraction of the public sphere and the public communication that was taking place in German mass media at the time. For Negt and Kluge, the public was always concrete, formed by actual people.

Public Sphere and Experience developed visions and examples of counterpublic spheres (which Negt and Kluge called proletarian public spheres), but it received a more open, momentary and concrete form in their later work Geschichte und Eigensinn, in which they focused directly on the idea of public spheres for production. ${ }^{8}$ Consequently, Negt and Kluge considered public spheres as societal spheres which were created around a phenomenon and a community and that always had a distinct life span. Public spheres were made and produced momentarily; they were actual and concrete; and they were places and forms for interventions and participation. ${ }^{9}$

If we take a look at the non-commercial practices or counter forces of film culture, the film workshops and co-ops turn up as primary material for research. A notable case is that of the Stockholm-based Film Workshop. The workshop was founded in 1973 by the Swedish Film Institute (SFI) and Swedish Radio (SR, the public Swedish Broadcasting Corporation), and lasted until 2001 when it was closed, despite protests from the filmmaking community. Browsing through the material, one is struck by the diversity of the participants. Old and young, Swedes and non-Swedes, men and women, professional filmmakers, established artists and authors as well as amateurs, asked for permission to use the facilities of the workshop in order to make films. Films encompassed a broad variety of forms and genres: documentary, educational, feature and animation as well as experimental work. During the twenty-eight years of the workshop more than four hundred films were finished (most of them on $16 \mathrm{~mm}$ ), and about 2,600 storyboards and sketches for films were sent to the workshop. 
Despite the size of the workshop, the number of films made, and the funding allocated by SFI and SR, the workshop has not left any trace in official Swedish film history. This absence is especially surprising given recent trends in film historiography, so-called new film history and film or media archaeology, which have questioned the teleological and totalizing strands in classical film history. ${ }^{10}$ One of the significant new contributions is Karen L. Ishizuka's and Patricia R. Zimmerman's co-edited book on amateur film, Mining the Home Movie. ${ }^{11}$ In one of the essays in the collection, Zimmerman argues that amateur film is the primary form which encompasses a "plurality of practices," difference and heterogeneity. ${ }^{12}$ Thus, according to Zimmerman, polyvocality is integral to the concept of amateur film.

The concept of polyvocality is derived from the historian Robert F. Berkhofer in his book Beyond the Great Story: History as Text and Discourse. ${ }^{13}$ Following Berkhofer, Zimmerman argues that the linguistic turn in film historiography has moved "history away from a single metanarrative [...] that is based on referentiality, realism, and facts that repress heterogeneity, toward a more particularized and multicultural construct of plural pasts." 14 It is the structure of these pluralities that form, or are, polyvocalities which in turn enable the "opening up [of] historical analysis to different explanatory models." Zimmerman pushes the concept further and argues that "polyvocalities [may act] as an explanatory model for disparate kinds of evidence and different kinds of interpretations." 15 It is striking how well polyvocality describes the way the Stockholm-based film workshop worked, and also how polyvocality may be regarded as an indicator of a functioning public sphere. Despite the fact that the Film Workshop was inaugurated by the state apparatus, the workshop soon found a model and a policy for its practice, mostly due to the long-term driving force at the workshop, Jan Bark, an experimental musician and composer who had some experience in filmmaking. Bark held onto the idea that the workshop should constitute an open space, and it was due to his policy that individuals and groups were able to tell their own stories. People shot their own footage and thereby created momentary public spheres through the use of film, regardless of the objectives of the funding bodies that strove for more useful outcomes. From the perspective of the institutions, it was a real problem that most of the filmmakers preferred to be free rather than professional filmmakers. ${ }^{16}$

"Polyvocalities" and "public sphere" are useful concepts in the analysis of film workshops, but "polyvocalities" should not only be reserved for amateur film. The Swedish workshops, for example, both the Film Centre and the Film Workshop, welcomed professional filmmakers. Though the increasing professionalization of the Film Centre led to a gradual exclusion of other filmmakers and practices, a rigid focus on amateur film, such as Zimmerman's, is equally exclusive. Therefore, it is necessary to consider the film workshops as being part of the practices of minor cinemas. 
David E. James elaborated on the concept of "minor cinemas," a term that he suggests as an "expanded summary term" for "experimental, poetic, underground, ethnic, amateur, counter, non-commercial, working-class, critical, artists', orphan, and so on." 17 The term "minor cinemas" was originally introduced by Tom Gunning who used it as a denominator for those experimental filmmakers who in the late 1980s criticized both the monumental position of Stan Brakhage and structural film for having become the metonym of avantgarde film (despite the fact that Brakhage and structural film were distinctively different). Gunning in turn adopted the term from Gilles Deleuze's and Félix Guattari's modern classic Kafka: Toward a Minor Literature. ${ }^{18}$ James rightly points out that there is no sense in calling Kafka "minor literature" in the common use of the word, but as a relational concept, signifying minor in its marginal position to dominant, the term makes sense. Another benefit of the concept is that it does not single out a particular group of films ("avant-garde," for example) or group of filmmakers (such as "amateurs"). Furthermore, the spatial and relational character of "minor" stresses its dependence on what is major or dominant, as was the case with the Swedish workshops; both major and minor were financed by the same institutions creating an intricate dialectic between centre and margin.

\section{THE FILM WORKSHOP AND FILM CENTRE}

The Stockholm-based film workshop was directly inspired by the Danish equivalent, "Filmworkshoppen" that was founded in $1970 .{ }^{19}$ As in Denmark, the workshop was financed by state television and the national foundation for film production, that is, in the Swedish case, by the two public channels, TV1 and TV2 at the SR and by the SFI. SFI and SR were primarily interested in the workshop because it could act as training and testing ground for semi-professional and even established filmmakers. The institutions were, however, also prepared to allow newcomers to make films, because in this way new people and fresh projects could be developed by major national institutions. The workshop was led by a steering committee that had financial responsibility and acted as the link between the acting committee of the workshop and the funding bodies. The acting committee was directly involved in the process of funding and supporting individual projects. It was the acting committee that decided which productions to support and that offered supervision to ongoing projects, and most importantly, adjusted the objectives according to the actual efforts that took place in the facilities.

It was stated in the first policies for the Film Workshop that the intention was to "primarily create a workshop for such projects that filmmakers could not realize in their regular production environment." Additionally, the purpose was to "offer artists and professionals the possibility to experiment with image and sound in order to expand cinema's means of expression." ${ }^{20}$ But the filmmakers 
did not really embrace experiments at the workshop, which was consequential to the organization. The Film Workshop was open and, due to the liberal attitude, most of the filmmakers wanted to express themselves and tell their stories, an approach that encouraged personal narratives and documentary modes. The first report produced by the Film Workshop in February 1974 states that more than $50 \%$ of the projects that had received support were documentaries. Only very few films were experimental and no proposals had been submitted by professional filmmakers. ${ }^{21}$ The documentaries produced during the first two years of the workshop ranged from personal portraits of male and female manual labourers, Man skall leva (You Shall Live, 1973) and Filmen om Linnea (The Film about Linnea, 1974), to socio-political depictions of suppressed groups such as disabled children or prisoners, Olyckliga barn (Unhappy Children) and Det är nog lite snett det där med vård (Custody Does Not Really Work), both from 1974. Most of the documentaries produced grew out of the filmmakers' personal relations to the subjects; the people who were given the chance to go public in front of the camera were usually persons whom the filmmakers already knew. The films made by immigrants reflected the gradual internationalization of Sweden and ranged from experimental shorts such as Miguel Cabeza's Plasma Breath (1973) to Muammer Özer's depiction of a Turkish immigrant story in Toprak Adam (1980). Accordingly, polyvocalities grew out of the practice of the workshop; the people running the activities at the workshop discovered how many different individuals and communities were out there and who really wanted to make films according to different purposes. The heterogeneous and multicultural ideal, as such, was never inscribed into the intentions of the funding and founding bodies.

It is quite evident that SFI and SR never really understood what they had launched when they founded the workshop. At first, SFI funded the workshop by allocating money reserved for short film production, and SR used money from their funds for research and development. Thus, the money used was a surplus resource, hence the activities were not highly prioritized by these funding agencies. When the financial situation tightened in 1982, the workshop was made into a foundation, and the budget was cut due to the reasoning that a foundation had the opportunity to apply for funding elsewhere. The decision to form a foundation was also an act that demonstrated how both SFI and SR had changed their attitude regarding the original objectives of the workshop. At first, the aim was to foster experiments and creativity, now the workshop was obliged to have clearly defined rationales in order to attract external funding. Finally, the workshop was closed in 2001 because, it was argued, the activities were so local they fit better into the regional film centre of Stockholm. The decision is proof of the fact that a transition from public good to public goods had taken place, as Habermas had envisioned in the early 1960s. The public sphere was no longer driven by the ideal of rational communication; instead, the public sphere had 
turned into a site for public consumption. ${ }^{22}$ Major governmental institutions had lost interest in funding public cultural activities for the sake of the public activity and replaced the previous policy with the objective to produce cultural products or events that would attract as many people as possible. This decision had its most evident effects in Europe when it came to public service, but it affected state funding for film too. For example, the initiative by the Swedish Film Institute to regionalize Swedish film culture and film production through the founding of regional film centres in 1997 was also a way of concentrating resources in order to secure the production of mainstream narrative features. The regional centres were given small sums of money with the objective to work with film culture in general; consequently, the Film Institute was able to focus on producing successful products.

It is worth comparing the Film Workshop with the Swedish co-operative that had been founded a few years earlier, FilmCentrum (Film Centre) in 1968. The Centre established polyvocality as their ideal and norm. The objective was both to reach the audience directly and to be in control of the means of production and distribution, hence being able to work independently from major companies and institutions. ${ }^{23}$ The Film Centre would add more turmoil to the constellation of institutions supporting free film in addition to reacting against what was considered "art" and regular feature filmmaking. ${ }^{24}$ The Centre aimed to avoid any categorization of film - short, documentary, feature, experimentala stance that did not make the organization's mission and work easy because the genres and the politics of funding at the Film Institute were quite rigid at the time. Many of the films distributed by the Centre were denied support or quality awards because they simply did not fit into the established regulations that primarily served the trade, the commercial producers, the established distributors and the owners of the theatres, or the art-cinema institution of the time. ${ }^{25}$ The Film Workshop, on the other hand, never faced this problem as they did not work with distribution.

The Film Centre was an emblematic child of its time, taking San Francisco's Canyon Cinema as one of its role models. ${ }^{26}$ Thus, it arose amidst the ethos of 1968 and was not a result of an institutional decision although the Centre also received state funding. As Duncan Reekie demonstrated in his book Subversion: The Definitive History of Underground Cinema, the American underground and the American co-ops inspired, influenced and acted in general as models for the European workshops. ${ }^{27}$ Even though the Film Centre was from the beginning an organization aimed solely at the distribution of independent film, and therefore it was not a workshop in the same sense as the Film Workshop, it did have an effect on production. Because of its work with independent and direct distribution, the Centre helped create a demand for different films and created a community for film projects that broke new ground. The Centre undoubtedly succeeded in enabling independently made films to reach an audience-part of its mission 
was to bring both filmmakers and new audiences together. ${ }^{28}$

The Centre became an important distribution nexus for artists, amateurs and students at the newly-founded first national film school of Sweden, the film school of the Swedish Film Institute (1964), and it worked extensively with international contacts. The film programs with which the Film Centre toured during its initial years were also very diverse. But the Film Centre was openly propagandistic in its activity and overtly declared its political affinities. This complicated the tours and the relation to the audience.

In order to become more powerful, the board of the Film Centre strongly supported the act of organizing the Swedish film workers into a union so that the film workers were able to be represented in vital institutions. The price paid for this tactic was that much of the focus and energy became concentrated on political questions; therefore, artists, amateurs and filmmakers in general, who did not consider themselves as professionals, left the organization. It was also because of the sharply-formulated political agenda that the Film Centre and the Film Workshop had difficulties cooperating.

Despite the exclusive political agenda, the Centre supported open admission and free distribution, a characteristic standpoint of the different workshops and co-ops of the period in Europe and North America. ${ }^{29}$ Nevertheless, when reading the minutes of Film Centre's first meeting, it is evident that the board was aware of the problem of the dialectics between inclusion and exclusion. In a memorandum from 27 June 1968, the core aim of the Centre was described as creating contact with the audience and films that would not reach an audience would be excluded, but to this was also added that the audience had to be fostered because it had been misled by the current politics of film culture. ${ }^{30}$ Accordingly, experimental work in particular would be questioned and therefore had a marginal position at the Centre's politics of distribution. ${ }^{31}$

The open character of the Film Centre was finally closed when professionally educated filmmakers entered the scene. Because film was their full-time occupation, union politics were brought into focus. As a result, it became more important to be able to control the means of production to gain positions and authority at the SFI and to influence government bodies. Thus, most of those who had chosen the Film Centre in order to find an audience for their films and who primarily wanted to explore the aesthetics of film, or, who just lacked an overt political agenda, left the Centre.

It is worth noting that whereas the Film Centre was overtly political in its strategies, it was the largely apolitical Film Workshop that in its practice became more political in a pragmatic sense. The Centre became geared towards professionalism, while the silenced or marginalized voices could be heard at the Workshop. ${ }^{32}$ Accordingly, the Film Workshop proved to be important as a public sphere in Negt's and Kluge's sense, as a social horizon of experience and a way of creating social spaces for marginal but collective experiences to be realized, 
and as a means for people to come together in order to produce cultural interventions in direct connection to their individual worlds. A significant number of the films were made by immigrants and female filmmakers. Thus, the Film Workshop constituted an important channel for marginalized groups and individuals to articulate and transmit experiences on other terms than those controlled by dominant media or institutions. An internal report on the Film Workshop from 1997 estimated that since the 1980s about $25 \%$ of the filmmakers at the Workshop were immigrants. ${ }^{33}$ This was a remarkable number given that in the 1980s hardly any Swedish feature films were made by immigrant filmmakers.

\section{FILMS FROM THE WORKSHOP: \\ FAGFUCKS, THE PLEDGE AND ...THIS IS THE WAY IT SHALL BE...}

An early film produced at the workshop was the short Bögjäular (Fagfucks, 1977, broadcast on public television in 1981), made by a team of eleven men. The group called the production company "Revolt Production," and the film received support both from the Workshop and the Swedish Association for Sexuality Education (RFSU). The film is essentially a documentary and an educational film about homosexuality made by a homosexual collective. The film presents its theme and subject through a personal voice. This shift from a rational public, Habermasian perspective to that of counter public is cleverly staged in the first two shots. The film begins with a boy lying on a couch reading an educational

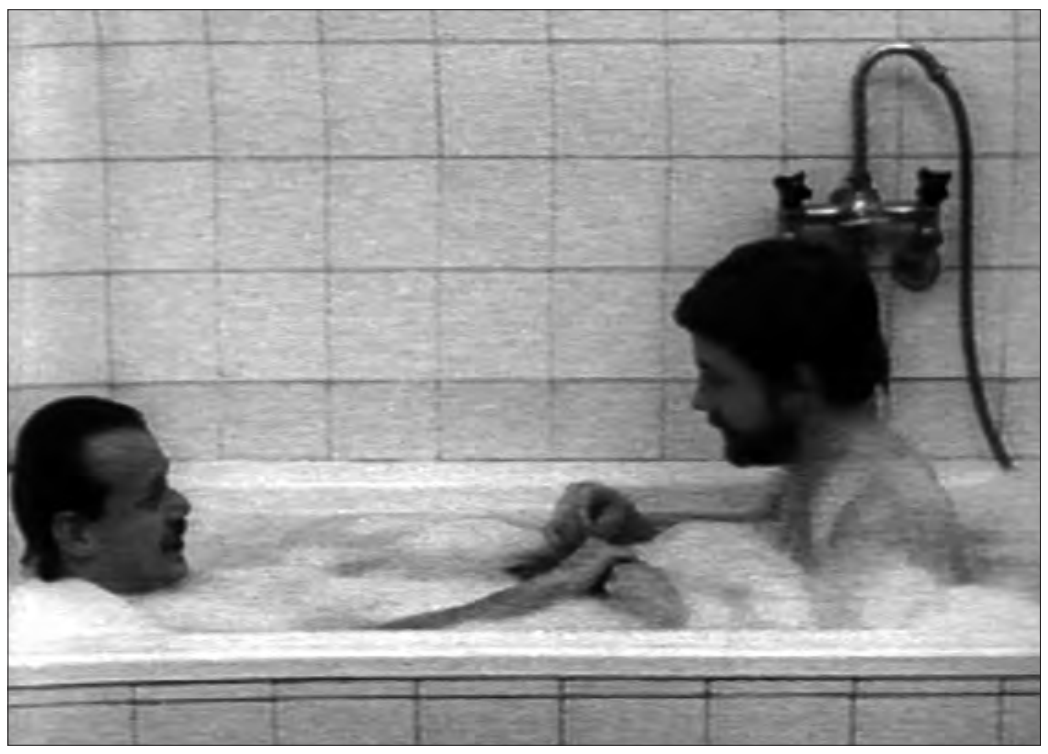

Revolt Production's Bögjävlar (Fagfucks, 1977). 
book about homosexuality. A scene in which two naked men are in a bathtub follows and includes diegetic sound that depicts the dialog between the two men, which is occasionally interrupted by a voice-over describing the experiences of a homosexual man. These scenes are an overt demonstration of how the collective filmmakers have taken over the right to speak with their own voices, capturing the voice of the rational public sphere and establishing a discourse that is precisely experience gone public, a public sphere in which the subjective and the objective converge. This aspect is stressed further in footage shot in the streets of Stockholm that displays how the collective is acting out its homosexuality while at the same time recording the reactions of the public.

Another interesting film is Löftet (The Pledge, 1984), a 35-minute narrative film made by the Greek immigrant, Menealos Carayannis. It tells a common immigrant story about how a man fails to succeed in a foreign country and who, therefore, returns home, but due to the hard manual labour he has been forced into, finds himself deprived of the abilities he had when he lived there before. The Pledge is one of many films shot by immigrants at the Film Workshop; the workshop was, in fact, almost the only way for immigrants to enter filmmaking in Sweden at the time.

Carayannis's film is not only a depiction of the immigrant experience; it is also a film that carefully deals with the position of the immigrant in public life. The film starts with the arrival of a Greek politician and officials at an airport who meet Greek demonstrators. From this initial shot of a public act in Greek (the banners are only in Greek), the film follows the male protagonist who works as a cleaner. The places he cleans are mostly cultural public arenas (theatres, artist's workshops, etc.). As an immigrant, he sneaks into these places in darkness to do his job. The man is also part of a theatre group at the local Greek association. However, due to the fact that he is always late for rehearsals, someone else is offered his part in the play. Accordingly, The Pledge is not only a film about a marginal group and its experiences; it is also a depiction of the necessity for a community to be able to create a cultural public sphere in order to make their voices heard. The dialog in The Pledge is mostly in Greek, which emphasizes the enclosed social and cultural space of the protagonists, and the film is shot in a realist style with long takes and no close-ups. The film ends with a scene showing the protagonist going home, accompanied by his wife and grandmother, thus sealing his fate and negating the hope established at the beginning in which a public was able to express its opinion. The immigrant who leaves Sweden is a crippled man in a wheelchair, unable to perform any action whatsoever.

The last example, the film ... det skall vara så här... (...this is the way it shall be..., 1985), is a film about menstruation. The film was made by Helena Lindgren who at the time had no previous filmmaking experience, however, ....this is the way it shall be... became so successful that it was shown on public service television and enabled Lindgren to proceed with filmmaking for Swedish television. 
The film was also distributed through Folkets Bio, (The People's Cinema), the theatrical chain connected with the Film Centre.

Lindgren's film is an experimental short that begins with a depiction of her grandmother telling how she experienced her first menstruation. This is followed by a rhythmically cut film that tells about menstruation as a biological fact and explains how it is experienced by various women. Towards the end of the film, menstruation is turned into a positive thing, much in the spirit of Fagfucks, stressing the force that the painful phenomenon possesses. While The Pledge is a critical tragedy, both Fagfucks and ...this is the way it shall be... are films aimed at raising the self-confidence of the group being addressed. These three films epitomize the ambition of the Film Workshop to carry out a minor cinema practice avant la lettre and give voice to otherwise marginalized experiences. In Fagfucks, the homosexual culture, everyday and underground at the same time, is sketched out in a manner new to Swedish film; The Pledge makes visible the hitherto invisible immigrant worker, the menial labourer in the shadow of the welfare state; and ... this is the way it shall be... shows us the corporeal facts of female sexuality, displaced by a patriarchal optics.

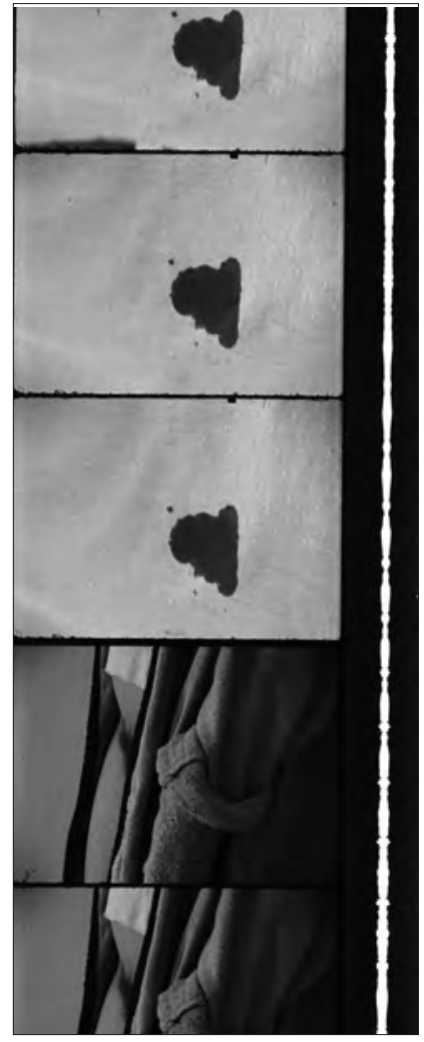

A strip of celluloid from Helena Lindgren's ... det skall vara så här... (...this is the way it shall be..., 1985)

\section{CONCLUSION: POLYVOCALITIES, PUBLIC SPHERE AND MINOR CINEMAS}

The Swedish film workshops-as well as their counterparts in several other European countries-remind us of the polyvocalities and stratifications of the public sphere. Our claim is that the workshops represent a minor cinema practice where traditional generic classification is of less importance, and where we need a new kind of mapping. In the field of the workshops, several minor cinemas merge: political documentary, archival footage, home movies, education film and experimental practices. They all function within an integrated culture where filmmaking is an element of a complex apparatus, encompassing social movements as well as avant-garde endeavours, and always with a relationship to governmental cultural policies in one way or another. Thus, the divide between amateur and professional is not a useful grid for analyzing film workshops. 
Another significant trait of the workshops is that they formed transnational spaces, in the manner of Ulrich Beck's concept of “inclusive distinction," enabling many different loyalties at the same time. ${ }^{34}$ The history of the workshops is an international and heterogeneous history beyond national imaginaries. Foreign filmmakers could stop by and work on their films while staying in Sweden and films could be produced at the Workshop although the films had no dialogue in Swedish. Hence, whereas state funded film production in Europe has typically been a way of reproducing and promoting national culture, at the Workshop there were no such requirements. Established experimental filmmakers, like Swedishborn Gunvor Nelson, who was based in America at the time, and the established London gallerist Maureen Paley, used the facilities to make significant works.

The strategic questions for film studies in the era of an expanding film and moving image culture seem to mirror the polyvocalities of the workshop cultures; questions concerning archival research and archival needs, questions connected to new film historiography, but also strands concerning cultural democracy and cultural policy, and the cultural heritage perspective. ${ }^{35}$ The workshop culture sketched in this essay is of twofold interest. First, there is an obvious need to portray and analyze the workshops as minor cinema practices, placing them in a context of film history, film politics and film aesthetics. The workshops are blank spots in film history. In our specific case, we want to consider the workshop practices of the Film Centre and the Film Workshop as chapters in Swedish film history, connecting the minor cinemas to diverse sectors of Swedish culture and media within the framework of theories of the public sphere. This does not mean, however, that we would stick to a "methodological nationalism"; the history is not so much a history of Swedes as it is a history of practices taking place in Sweden, and as the country became increasingly international due to ever more immigration as well as economical and cultural globalization during these years, the local practices were often transnational in character. Second, there is a huge amount of knowledge that we can access through the workshops, research valued beyond film studies proper. Such research might include, for example, histories of the institutionalization of cultural policies during the 1960s and 1970s, or documentation of the interaction between the workshops and institutions such as compulsory schools, art communities, university departments, trade unions and political parties. Study of the workshops might also reveal new understandings about the growth of a multicultural Europe and the transnationalization of formerly exclusive national practices (as European state film production in particular has often been).

In closing, we would like to point out three fields of particular interest that combine the perspectives of film history and theories of the public sphere:

- The need for an integrated archival policy, which not only takes care of the workshop culture as the "reel thing," but also includes other kinds of material remnants that constitute the vast and integrated archive of the film workshops 
as a cultural and social movement: letters, applications, policy documents, scripts, stills, programming, program notes, minutes and protocols.

- The need for a new film history that can understand and communicate the workshop cultures as minor cinema practices and consider them in various cultural and filmic contexts. This implies a shift regarding film history and film culture, beyond the dominance of feature film or the binaries between amateur and professional, fiction and documentary, film (object) and audience (subject), avant-garde and mainstream and so forth.

- The importance of the critique of a methodological nationalism, of considering the workshops as transnational spaces that at the level of practice worked beyond the binary of national and international, constituting true "glocal" places for filmmaking and film viewing not beyond borders, but as polyvocal public spheres.

Bjørn Sørenssen shows how YouTube works as a vector merging diverse communities and publics that hitherto have never met. This was also often the case with the film workshops. The question of a functional public sphere though is a matter of both norm and concretization, a fusion of the positions that Habermas and Negt and Kluge represent. Compared to the Film Centre, the Stockholmbased Film Workshop proved to work like a proper public sphere. The everyday organization and the state funding of the workshop was a guarantee that no single voice or film form was favoured, and each filmmaker was able to make films on their own terms. Hence, the decision of the Swedish Film Institute in 2001 to close down the workshop meant a denial of both Habermas's and Negt's and Kluge's conceptions. Now we have to look for the minor cinemas elsewhere.

\section{NOTES}

1. Oskar Negt and Alexander Kluge, Public Sphere and Experience (Minnesota: University of Minnesota Press, 1993).

2. Bjørn Sørenssen, "Digital Video and Alexandre Astruc's Caméra-Stylo: the New AvantGarde in Documentary Realized?" Studies in Documentary Film 2, no. 1 (2008): 47-59.

3. Miriam Hansen, Babel and Babylon: Spectatorship in American Silent Film (Cambridge, MA: Harvard University Press, 1996), 108.

4. Ibid., 129.

5. For example, Malte Hagener, Moving Forward, Looking Back: The European Avant-garde and the Invention of Film Culture, 1919 - 1939 (Amsterdam: Amsterdam University Press, 2007); David E. James, The Most Typical Avant-Garde: History and Geography of Minor Cinemas in Los Angeles (Berkeley: University of California Press, 2005); and David E. James, "For a Working-Class Television: The Miners' Campaign Tape Project," Power Misses: Essays Across (Un)Popular Culture (London: Verso Books, 1996), 248-265.

6. For a German contextualization of the work see Loren Kruger's review of the book in Modernism/Modernity 1:3 (1994): 240-243.

7. Nancy Fraser, "Rethinking the Public Sphere: A Contribution to the Critique of Actually Existing Democracy," in Habermas and the Public Sphere, ed. Craig Calhoun (Cambridge, MA: MIT Press, 1992), 109-142; Johan Fornäs, Cultural Theory and Late Modernity (London: Sage Publications, 1995).

8. Usually translated as "History and Obstinacy", Frederic Jameson suggests, however, 
"History and Self-Will" better covers the idea of resistance and the concreteness of counter publics. Frederic Jameson "On Negt and Kluge," October 46 (Fall 1988): 158. Oskar Negt and Alexander Kluge, Geschichte und Eigensinn (Frankfurt am Main: Zweitausendeins, 1981).

9. See, for example, the interview by Monika Krause, "The Production of Counter-Publics and the Counter-Publics of Production: An Interview with Oskar Negt," European Journal of Social Theory 9, no. 1 (2006): 119-128.

10. See, for example, Lars Gustaf Andersson and John Sundholm, "Amateur and AvantGarde: Minor Cinemas and Public Sphere in 1950s Sweden," Studies in European Cinema 5, no. 3 (2008): 207-218 and Thomas Elsaesser, "The New Film History as Media Archaeology," Cinémas 14, no. 2-3 (2004): 75-117.

11. Karen L. Ishizuka and Patricia R. Zimmerman, eds., Mining the Home Movie: Excavations in History and Memory (Berkeley: University of California Press, 2007).

12. Patricia R. Zimmerman, "Morphing History into Histories: From Amateur Film to the Archive of the Future," in Mining the Home Movie: Excavations in History and Memory (Berkeley: University of California Press, 2007), 275.

13. Robert F. Berkhofer, Beyond the Great Story: History as Text and Discourse (Cambridge, MA: Harvard University Press, 1995).

14. Patricia R. Zimmerman, "Introduction: The Home Movie Movement: Excavations, Artifacts, Minings," in Mining the Home Movie: Excavations in History and Memory (Berkeley: University of California Press, 2007), 5.

15. Ibid.

16. This was stated by Kjell Grede, established filmmaker who was the director of the workshop during the initial years, in a report dated 21 February 1974. He complained that no professional filmmaker approached the workshop and that those filmmakers who did were "more free than filmmakers." Kjell Grede, "Filmverkstan (FV) i februari 1974" (Unpublished report, SFI Archive, Stockholm), 2.

17. James, The Most Typical Avant-Garde, 13.

18. Tom Gunning, "Towards a Minor Cinema: Fonoroff, Herwitz, Ahwesh, Lapore, Khlar and Solomon," Motion Picture 3, no. 1-2 (1990): 2-5. The term "minor cinema" is put in context by Gary Genosko in his Félix Guattari: A Critical Introduction (London: Pluto Press, 2009), 134-157, where he also discusses terms like "nomadic cinema" and "imperfect cinema." The latter connected to Julio García Espinosa and his analysis of Latin American cinema.

19. Helge Krarup and Carl Nørrested, Eksperimentalfilm i Danmark (København: Borgen, 1986); Susanna Neimann, ed., En støj i øjet: Film- og videoeksperimenter på danske værkstæder (Aarhus: KLIM, 1989).

20. Letter from SFI to Filmform, FilmCentrum, the national association for substandard filmmaking and the association of film directors. 13 December 1972.

21. Grede, 2-3.

22. Jürgen Habermas, Structural Transformation of the Public Sphere: An Inquiry into a Category of Bourgeois Society (Cambridge, MA: MIT Press, 1989).

23. For example, Författarcentrum ("Writers Centre") and Teatercentrum ("Theatre Centre"). The former was the first, founded in 1967.

24. This is evident in Svenstedt's history of the founding of the Film Centre, published as a pamphlet in 1970, Arbetarna lämnar fabriken: Filmindustrin blir folkrörelse [Workers leaving the factory: The film industry becomes a people's movement] (Stockholm: Norstedts, 1970). See especially the interview with the filmmakers Lena Ewert and Lars Westman included in the pamphlete.

25. One of the most controversial cases developed around the documentary Rekordarren 1967, 1968, 1969 [The Record Years 1967, 1968, 1969, 1968]-a film about the politics of urban planning. It was shot on $16 \mathrm{~mm}$ by students at the national film school. Although the film is feature length, it was not distributed commercially in theaters and 
could, therefore, not receive any quality awards despite having received the quality points required.

26. For a history of Canyon Cinema see Scott MacDonald's Canyon Cinema: The Life and Times of an Independent Film Distributor (Berkeley: University of California Press, 2008).

27. Duncan Reekie, Subversion: The Definitive History of Underground Cinema (London: Wallflower Press, 2007), 146-158.

28. This was, in fact, a very hard task and Svenstedt has estimated that only about a dozen filmmakers actually acted according to the mission (interview with Carl Henrik Svenstedt, 1 May 2008). Amateur filmmaker Sven Elfström quit touring in 1972 because of the harsh work and adverse conditions (interview with Sven Elfström, 28 April 2008).

29. This was, of course, under debate in those countries as well. In the U.S., Jonas Mekas always supported no selection, whereas Brakhage famously withdrew his films for a short period in 1967 from the New York Co-op because it refused selection and, therefore, "advertised violence, hatred, dope, self-centred love, nihilism." Paul Arthur, A Line of Sight: American Avant-Garde Film Since 1945 (Minnesota: University of Minnesota Press, 2005), 15.

30. "Redogörelse för arbetet med en icke-kommersiell filmkatalog avsedd att ligga till grund för ett FILMCENTRUM," Film Centre memo, 27 June 1968, Filmform Archive .

31. In a transcription of the discussion during the annual meeting of the Film Centre, published in the Centre's reports Rapport från FilmCentrum no. 11 (1970), Svenstedt expresses the opinion that the Film Centre would become marginalized if it confirmed the image presented by its opponents, namely that the Centre was the mouthpiece for a small group of experimental filmmakers (21). Ralph Lundsten's (a key figure in Sweden's experimental music and film scene in the 60s) early reaction from 1974 is, therefore, consequential. He felt that Film Centre had become hijacked by politics and wrote an open statement in the Centre's journal Film \& TV, in which he called for a focus on distribution of all independently made films as well as those made by "other" filmmakerspeople whose political stances were either controversial or indifferent in relation to the dominant views of the co-op. Lundsten's open letter, "Brev till Film\&TV," was published in Film \& TV, no. 1-2 (1974): 59.

32. In fact this was a critique that Eric M. Nilsson expressed against the Film Centre in an interview from 1976. According to Nilsson it was obvious that most of the filmmakers at the Centre had a voice; they were able to express themselves and had the power to address people. See Film \& TV, no. 7-8 (1976): 10.

33. Claes Österholm, "Filmverkstan 1997," (Unpublished report, SFI Archive, Stockholm) 9.

34. Ulrich Beck, What is Globalization? (Cambridge: Polity Press, 2000).

35. On the expanding notion of the archive-including material other than commercial and national-and the democratization of film history. See, for example, Zimmerman, "Introduction," 5 and Thomas Elsaesser, "Ingmar Bergman in the Museum?: Thresholds, Limits, Conditions of Possibility," Journal of Aesthetics \& Culture 1 (2009), http://www.aestheticsandculture.net/index.php/jac/article/view/2123/261 1 (accessed on 25 May 2010).

LARS GUSTAF ANDERSSON, Associate Professor, Film Studies, Lund University, Sweden. Research within European art cinema and Swedish film history. JOHN SUNDHOLM, Associate Professor, Film Studies, Karlstad University, Sweden. On the examination board of the PhD-program in Fine Arts, Academy of Fine Arts in Helsinki, Finland. Research within experimental cinema and memory studies.

Together with Astrid Söderbergh Widding they have published A History of Swedish Experimental Film Culture: From Early Animation to Video Art (Stockholm: National Library of Sweden 2010). 